\title{
Front Matter: Volume 7373
}

, "Front Matter: Volume 7373," Proc. SPIE 7373, Therapeutic Laser Applications and Laser-Tissue Interactions IV, 737301 (3 August 2009); doi: 10.1117/12.836570

SPIE. Event: European Conferences on Biomedical Optics, 2009, Munich, Germany 


\title{
Therapeutic Laser Applications and Laser-Tissue Interactions IV
}

\author{
Ronald Sroka \\ Lothar D. Lilge \\ Editors
}

\section{7-18 June 2009}

Munich, Germany

Sponsored and Published by

Optical Society of America (United States)

SPIE

Cooperating Organisation

German Biophotonics Research Program (Germany)

Cosponsored by

Photonics4Life-European Network of Excellence for Biophotonics

Air Force Office of Scientific Research (United States) 
The papers included in this volume were part of the technical conference cited on the cover and title page. Papers were selected and subject to review by the editors and conference program committee. Some conference presentations may not be available for publication. The papers published in these proceedings reflect the work and thoughts of the authors and are published herein as submitted. The publisher is not responsible for the validity of the information or for any outcomes resulting from reliance thereon.

Please use the following format to cite material from this book:

Author(s), "Title of Paper," in Therapeutic Laser Applications and Laser-Tissue Interactions IV, edited by Ronald Sroka, Lothar D. Lilge, Proceedings of SPIE-OSA Vol. 7373 (SPIE, Bellingham, WA, 2009) Article CID Number.

ISSN 1605-7422

ISBN 9780819476494

Published by

SPIE

P.O. Box 10, Bellingham, Washington $98227-0010$ USA

Telephone +1 3606763290 (Pacific Time) · Fax +1 3606471445

SPIE.org

Optical Society of America

2010 Massachusetts Ave., N.W., Washington, D.C., 20036 USA

Telephone 1 202/223-8130 (Eastern Time) · Fax 1 202/223-1096

http://www.osa.org

Copyright ( 2009, Society of Photo-Optical Instrumentation Engineers and Optical Society of America.

Copying of material in this book for internal or personal use, or for the internal or personal use of specific clients, beyond the fair use provisions granted by the U.S. Copyright Law is authorized by SPIE subject to payment of copying fees. The Transactional Reporting Service base fee for this volume is $\$ 18.00$ per article (or portion thereof), which should be paid directly to the Copyright Clearance Center (CCC), 222 Rosewood Drive, Danvers, MA 01923. Payment may also be made electronically through CCC Online at copyright.com. Other copying for republication, resale, advertising or promotion, or any form of systematic or multiple reproduction of any material in this book is prohibited except with permission in writing from the publisher. The CCC fee code is $1605-7422 / 09 / \$ 18.00$.

Printed in the United States of America.

Publication of record for individual papers is online in the SPIE Digital Library.

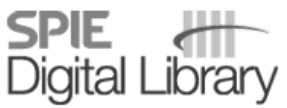

SPIEDigitalLibrary.org

Paper Numbering: Proceedings of SPIE follow an e-First publication model, with papers published first online and then in print and on CD-ROM. Papers are published as they are submitted and meet publication criteria. A unique, consistent, permanent citation identifier (CID) number is assigned to each article at the time of the first publication. Utilization of CIDs allows articles to be fully citable as soon they are published online, and connects the same identifier to all online, print, and electronic versions of the publication. SPIE uses a six-digit CID article numbering system in which:

- The first four digits correspond to the SPIE volume number.

- The last two digits indicate publication order within the volume using a Base 36 numbering system employing both numerals and letters. These two-number sets start with 00, 01, 02, 03, 04, 05, 06, 07, 08, 09, OA, OB ... OZ, followed by 10-1Z, 20-2Z, etc.

The CID number appears on each page of the manuscript. The complete citation is used on the first page, and an abbreviated version on subsequent pages. Numbers in the index correspond to the last two digits of the six-digit CID number. 


\section{Contents}

ix Conference Committees

xi Introduction

\section{CELLULAR SURGERY II}

$737308 \quad$ Nanoparticle mediated laser cell perforation [7373-34]

M. Schomaker, J. Baumgart, Laser Zentrum Hannover e.V. (Germany) and Research Cluster of Excellence REBIRTH (Germany); A. Ngezahayo, Institute of Biophysics, Leibniz Univ. (Germany); J. Bullerdiek, Univ. of Veterinary Medicine Hannover (Germany), Research Cluster of Excellence REBIRTH (Germany), and Univ. of Bremen (Germany); I. Nolte, Univ. of Veterinary Medicine Hannover (Germany) and Research Cluster of Excellence REBIRTH (Germany); H. Murua-Escobar, Univ. of Veterinary Medicine Hannover (Germany), Research Cluster of Excellence REBIRTH (Germany), and Univ. of Bremen (Germany); H. Lubatschowski, A. Heisterkamp, Laser Zentrum Hannover e.V. (Germany) and Research Cluster of Excellence REBIRTH (Germany)

7373 OC Femtosecond-laser-based enucleation of porcine oocytes for somatic cell nuclear transfer [7373-11]

K. Kütemeyer, Laser Zentrum Hannover e.V. (Germany); A. Lucas-Hahn, B. Petersen, P. Hassel, E. Lemme, H. Niemann, Friedrich-Loeffler-Institute of Farm Animal Genetics (Germany); A. Heisterkamp, Laser Zentrum Hannover e.V. (Germany)

\section{OPTHALMOLOGY}

7373 OD Dynamics of laser-induced transient micro bubble clusters [7373-72]

A. Fritz, L. Ptaszynski, H. Stoehr, Medizinisches Laserzentrum Lübeck GmbH (Germany); R. Brinkmann, Medizinisches Laserzentrum Lübeck GmbH (Germany) and Univ. zu Lübeck (Germany)

$7373 \mathrm{OE}$ Time resolved detection of tissue denaturation during retinal photocoagulation [7373-8] K. Schlott, Medizinisches Laserzentrum Lübeck GmbH (Germany) and Univ. zu Lübeck (Germany); J. Langejürgen, Univ. zu Lübeck (Germany); M. Bever, Medizinisches Laserzentrum Lübeck GmbH (Germany); S. Koinzer, Univ. Kiel (Germany); R. Birngruber, R. Brinkmann, Medizinisches Laserzentrum Lübeck GmbH (Germany) and Univ. zu Lübeck (Germany)

$7373 \mathrm{OH} \quad$ Femtosecond-lentotomy treatment: six-month follow-up of in vivo treated rabbit lenses [7373-30]

S. Schumacher, M. Fromm, Laser Zentrum Hannover e.V. (Germany); U. Oberheide, Laserforum Köln e.V. (Germany); P. Bock, I. Imbschweiler, Univ. of Veterinary Medicine Hannover (Germany); H. Hoffmann, Laser Zentrum Hannover e.V. (Germany); A. Beineke, Univ. of Veterinary Medicine Hannover (Germany); G. Gerten, Laserforum Köln e.V. (Germany); A. Wegener, Univ. of Bonn (Germany); H. Lubatschowski, Laser Zentrum Hannover e.V. (Germany) 
7373 ol Photobleaching of a human donor lens using an $\mathbf{8 0 0 - n m ~ f e m t o s e c o n d ~ T i : S a p p h i r e ~ l a s e r ~}$ [7373-36]

L. Kessel, Copenhagen Univ. Hospital Glostrup (Denmark); L. Eskildsen, Copenhagen Univ. Hospital Glostrup (Denmark) and Technical Univ. of Denmark (Denmark); M. van der Poel, Technical Univ. of Denmark (Denmark); M. Larsen, Copenhagen Univ. Hospital Glostrup (Denmark)

$73730 \mathrm{~J}$ Wavelength optimization in femtosecond laser corneal surgery: experimental results [7373-24]

C. Crotti, F. Deloison, D. A. Peyrot, Lab. d'Optique Appliquée, Ecole Nationale Supérieure de Techniques Avancées, CNRS (France); M. Savoldelli, J.-M. Legeais, Lab. Biotechnologie et OEil, Hôpital Hôtel Dieu de Paris (France); F. Roger, Unité de Mécanique, Ecole Nationale Supérieure de Techniques Avancées (France); K. Plamann, Lab. d'Optique Appliquée, Ecole Nationale Supérieure de Techniques Avancées, CNRS (France)

NOVEL APPROACHES

7373 OK Dependence of optoacoustic transients on exciting laser parameters for real-time monitoring of retinal photocoagulation [7373-44]

J. Langejürgen, Univ. zu Lübeck (Germany); K. Schlott, M. Bever, K. Hausmann, Medizinisches Laserzentrum Lübeck GmbH (Germany); S. Koinzer, Univ. Hospital of Schleswig-Holstein (Germany); L. Ptaszynski, Medizinisches Laserzentrum Lübeck GmbH (Germany); J. Roider, Univ. Hospital of Schleswig-Holstein (Germany); R. Birngruber, Medizinisches Laserzentrum Lübeck GmbH (Germany); R. Brinkmann, Univ. zu Lübeck (Germany) and Medizinisches Laserzentrum Lübeck GmbH (Germany)

$7373 \mathrm{OL}$ Dynamic and interaction of fs-laser-induced cavitation bubbles for analyzing the cutting effect [7373-27]

N. Tinne, S. Schumacher, V. Nuzzo, T. Ripken, H. Lubatschowski, Laser Zentrum Hannover e.V. (Germany)

7373 ON Development of a localized x-ray source for the pin-point treatment of cancers using femtosecond laser [7373-23]

N. Kawashima, Kinki Univ. (Japan); H. Muramatsu, C. Yanagimoto, Laserck Inc. (Japan); M. Miyazawa, E. Kajiwara, Kinki Univ. School of Medicine (Japan); K. Imasaki, Osaka Univ. (Japan)

737300 Characterizing fluorescence spectral features of cancer, benign, and normal human breast tissues through wavelet transform and singular value decomposition [7373-52] A. H. Gharekhan, A. N. Oza, C. U. Shah Science College, Gujarat Univ. (India); M. B. Sureshkumar, M.S. Univ. of Baroda (India); P. K. Panigrahi, Physical Research Lab. (India) and Indian Institute of Science Education Research (India); A. Pradhan, Indian Institute of Technology Kanpur (India) 
7373 OP Multifractal spectra of laser Doppler flowmetry signals in healthy and sleep apnea syndrome subjects [7373-32]

B. Buard, Groupe ESAIP (France) and Univ. d'Angers (France); W. Trzepizur, Lab. de Physiologie et d'Explorations Vasculaires, CNRS, Ctr. Hospitalier Univ. d'Angers (France) and Ctr. Hospitalier Univ. d'Angers (France); G. Mahe, Lab. de Physiologie et d'Explorations Vasculaires, CNRS, Ctr. Hospitalier Univ. d'Angers (France); F. Chapeau-Blondeau,

D. Rousseau, Univ. d'Angers (France); F. Gagnadoux, Ctr. Hospitalier Univ. d'Angers (France); P. Abraham, Lab. de Physiologie et d'Explorations Vasculaires, CNRS, Ctr. Hospitalier Univ.

d'Angers (France); A. Humeau, Groupe ESAIP (France) and Univ. d'Angers (France)

\section{PHOTODYNAMIC THERAPY I}

7373 OR Merocyanine-540 mediated photodynamic effects on Staphylococcus epidermidis biofilms [7373-20]

M. S. Sbarra, A. Di Poto, E. Saino, L. Visai, Univ. degli Studi di Pavia (Italy); P. Minzioni, F. Bragheri, I. Cristiani, Consorzio Nazionale Interuniversitario per le Scienze Fisiche della Materia (Italy) and Univ. degli Studi di Pavia (Italy)

7373 OS Photochemical model of photodynamic therapy applied to skin diseases by a topical photosensitizer [7373-59]

F. Fanjul-Vélez, I. Salas-García, L. A. Fernández-Fernández, Univ. de Cantabria (Spain); M. López-Escobar, Univ. Hospital Marqués de Valdecilla (Spain); L. Buelta-Carrillo,

N. Ortega-Quijano, J. L. Arce-Diego, Univ. de Cantabria (Spain)

MODELING

737313 GPU-accelerated Monte Carlo simulation for photodynamic therapy treatment planning [7373-65]

W. C. Y. Lo, T. D. Han, J. Rose, L. Lilge, Univ. of Toronto (Canada)

737315 A combined mathematical-physical model of laser-induced thermotherapy (LITT) [7373-54] M. S. Enevoldsen, O. Skovgaard, P. E. Andersen, Technical Univ. of Denmark (Denmark)

737316 Effect of skin tumor properties on laser penetration [7373-69]

A. E. Karsten, Council for Scientific and Industrial Research (South Africa) and Univ. of Pretoria (South Africa); A. Singh, Council for Scientific and Industrial Research (South Africa)

737317 Determination of the optical properties of PNIPAAm gels used in biological applications [7373-13]

A. Singh, A. E. Karsten, I. Mputle, A. Chetty, K. Naidoo, Council For Scientific and Industrial Research (South Africa)

\section{CLINICAL LASER THERAPY}

7373 lA Femtosecond laser microstructuring of titanium surfaces for middle ear ossicular replacement prosthesis: results of preliminary studies [7373-14]

S. Biedron, J. F. R. Ilgner, RWTH Aachen Univ. Hospital (Germany); E. Fadeeva, B. Chichkov, Laser Zentrum Hannover e.V. (Germany); A. Prescher, M. Bovi, RWTH Aachen Univ.

(Germany); M. Westhofen, RWTH Aachen Univ. Hospital (Germany) 
7373 1B Partial porcine kidney resection in vivo using a $1.92 \mu \mathrm{m}$ fiber laser system [7373-17] D. Theisen-Kunde, Medical Laser Centre Lübeck GmbH (Germany) and Univ. zu Lübeck (Germany); S. Tedsen, Univ. Hospital Schleswig-Holstein (Germany); V. Danicke,

R. Brinkmann, Univ. zu Lübeck (Germany)

7373 1D Endovenous laser treatment (EVLT) of safernous vein reflux with $1.56 \mu \mathrm{m}$ laser [7373-21] V. P. Minaev, IRE-Polus Co. (Russian Federation); A. L. Sokolov, K. V. Lyadov, M. M. Lutsenko, Ministry of Health (Russian Federation); K. M. Zhilin, IRE-Polus Co. (Russian Federation)

$7373 \mathrm{IE}$ Selective treatment of atherosclerotic plaques using nanosecond pulsed laser with a wavelength of $5.75 \mu \mathrm{m}$ for less-invasive laser angioplasty [7373-31]

K. Ishii, H. Tsukimoto, H. Hazama, K. Awazu, Osaka Univ. (Japan)

\section{POSTER SESSION}

$737311 \quad$ Evaluation of the PDT effect of Foscan and Fospeg in the LNCaP human prostate cancer cell line [7373-12]

A. Petri, M. Kyriazi, E. Alexandratou, National Technical Univ. of Athens (Greece); M. Rallis, National and Kapodistrian Univ. of Athens (Greece); S. Gräfe, biolitec AG (Germany);

D. Yova, National Technical Univ. of Athens (Greece)

7373 1L Photodynamic inactivation of the models Mycobacterium phlei and Mycobacterium smegmatis in vitro [7373-03]

R. Bruce-Micah, Apocare Pharma GmbH (Germany); U. Gamm, Univ. Kaiserslautern (Germany); D. Hüttenberger, Apocare Pharma GmbH (Germany); J. Cullum, H.-J. Foth, Univ. Kaiserslautern (Germany)

$73731 \mathrm{M}$ Characterization of a miniature integrating cylinder for absolute calibration of fluence rate probes for interstitial photodynamic therapy (IPDT) [7373-50]

B. Lai, Ontario Cancer Institute (Canada) and Univ. of Toronto (Canada); G. Netchev, Ontario Cancer Institute (Canada); E. Henderson, L. Lilge, Ontario Cancer Institute (Canada) and Univ. of Toronto (Canada)

7373 iN Absolute calibration of multi-sensor fluorescent probes for interstitial photodynamic therapy monitoring [7373-06]

B. Lai, L. D. Lilge, Ontario Cancer Institute (Canada) and Univ. of Toronto (Canada)

$73731 Q \quad$ Optical parameters evaluation using optical coherent tomography images [7373-68]

I. Ionita, Univ. of Bucharest (Romania)

7373 IR The modeling of the temperature field formed inside multilayered biological tissue under laser emission [7373-35]

K. G. Kulikov, St. Petersburg Polytechnical State Univ. (Russian Federation)

7373 is Comparison of 980-nm and 1070-nm in endovenous laser treatment (EVLT) [7373-37]

N. Topaloglu, O. Tabakoglu, Bogaziçi Üniv. (Turkey); M. U. Ergenoglu, Yeditepe Univ. Hospital (Turkey); M. Gülsoy, Bogaziçi Üniv. (Turkey) 
7373 IT Laser osteoperforation for treatment of inflammatory and destructive bone diseases [7373-60]

V. A. Privalov, Chelyabinsk State Medical Academy (Russian Federation); I. V. Krochek, Chelyabinsk Municipal Hospital (Russian Federation); I. A. Abushkin, I. I. Shumilin, Chelyabinsk State Medical Academy (Russian Federation); A. V. Lappa, Chelyabinsk State Univ. (Russian Federation)

7373 IU Root canal microleakage investigation after Nd:YAG laser-assisted treatment [7373-45] C. Balabuc, L. Filip, M. Calniceanu, Univ. de Medicina si Farmacie Victor Babes, Timisoara (Romania); C. Demian, A. Raduta, C. Locovei, Politehnica Univ. Timisoara (Romania); C. Todea, Univ. de Medicina si Farmacie Victor Babes, Timisoara (Romania)

7373 IV Optical tweezers and manipulation of PMMA beads in various conditions [7373-26] D. G. Kotsifaki, M. Makropoulou, A. A. Serafetinides, National Technical Univ. of Athens, Zografou (Greece)

7373 1X Non-ablative processing of biofibers by femtosecond IR laser [7373-29]

V. Hovhannisyan, W. Lo, National Taiwan Univ. (Taiwan); C. Hu, Industrial Technology Research Institute South (Taiwan); S.-J. Chen, National Cheng Kung Univ. (Taiwan); C. Y. Dong, National Taiwan Univ. (Taiwan)

$73731 \mathrm{Y}$ Study of corneal scattering for the optimization of femtosecond keratoplasty [7373-63] D. A. Peyrot, Lab. d'Optique Appliquée, CNRS, Ecole Nationale Supérieure de Techniques Avancées (France); F. Aptel, Lab. Biotechnologie et OEil, Hôpital Hôtel Dieu, Univ. Paris Descartes (France); C. Crotti, F. Deloison, Lab. d'Optique Appliquée, CNRS, Ecole Nationale Supérieure de Techniques Avancées (France); M. Savoldelli, J.-M. Legeais, Lab. Biotechnologie et OEil, Hôpital Hôtel Dieu, Univ. Paris Descartes (France); K. Plamann, Lab. d'Optique Appliquée, CNRS, Ecole Nationale Supérieure de Techniques Avancées (France) and Lab. Biotechnologie et OEil, Hôpital Hôtel Dieu, Univ. Paris Descartes (France)

737320 Transmission measurements of human lenses [7373-07]

J. H. Lundeman, K. Herbst, M. Larsen, L. Kessel, Copenhagen Univ. Hospital Glostrup (Denmark)

737321 Atomic force microscopy analysis of human cornea after UV ( $\lambda=\mathbf{2 6 6} \mathbf{n m}$ ) laser irradiation [7373-43]

E. Spyratou, M. Makropoulou, K. Moutsouris, C. Bacharis, A. A. Serafetinides, National Technical Univ. of Athens, Zografou (Greece)

Author Index 
Downloaded From: https://www.spiedigitallibrary.org/conference-proceedings-of-spie on 25 Apr 2023

Terms of Use: https://www.spiedigitallibrary.org/terms-of-use 


\title{
Conference Committee
}

\author{
Symposium Chairs
}

Mary-Ann Mycek, University of Michigan (United States)

Wolfgang Drexler, Cardiff University (United Kingdom)

Program Chairs

Christoph K. Hitzenberger, Medical University of Vienna (Austria)

Brian W. Pogue, Dartmouth College (United States)

Conference Chairs

Ronald Sroka, Ludwig-Maximilians-Universität München (Germany)

Lothar D. Lilge, University Health Network, Ontario Cancer Institute

(Canada)

Program Committee

Stefan Andersson-Engels, Lunds Tekniska Högskola (Sweden)

Wolfgang Bäumler, Universitätsklinikum Regensburg (Germany)

Stephen G. Bown, University College London (United Kingdom)

Ralf Brinkmann, Universität zu Lübeck (Germany)

Martin Frenz, Universität Bern (Switzerland)

Christoph Haisch, Technische Universität München (Germany)

Michael R. Hamblin, Harvard Medical School (United States)

Raimund Hibst, Universität UIm (Germany)

Colin Hopper, Eastman Dental Institute (United Kingdom)

E. Duco Jansen, Vanderbilt University (United States)

Barbara E. Krammer, Universität Salzburg (Austria)

Mladen Korbelik, British Columbia Cancer Agency (Canada)

Serge R. Mordon, INSERM, Pavillon Vancostenobel (France)

Ethne L. Nussbaum, University of Toronto (Canada)

Dominic J. Robinson, Erasmus Universiteit Medisch Centrum Rotterdam

(Netherlands)

Ricardas Rotomskis, Vilnius University (Lithuania)

Herbert G. Stepp, Ludwig-Maximilians-Universität München (Germany)

Alfred Vogel, Universität zu Lübeck (Germany)

Georges A. Wagnieres, Ecole Polytechnique Fédérale de Lausanne

(Switzerland)

Timothy C. Zhu, The University of Pennsylvania (United States) 
Session Chairs

Cellular Surgery I

Lothar D. Lilge, Ontario Cancer Institute (Canada)

Alfred Vogel, Universität zu Lübeck (Germany)

Cellular Surgery II

Ralf Brinkmann, Universität zu Lübeck (Germany)

Wolfgang Baeumler, Universitätsklinikum Regensburg (Germany)

Opthalmology

Martin Frenz, Universität Bern (Switzerland)

Novel Approaches

Christoph Haisch, Technische Universität München (Germany)

Ronald Sroka, Ludwig-Maximilians-Universität München (Germany)

Photodynamic Therapy I

Barbara E. Krammer, Universität Salzburg (Austria)

Photodynamic Therapy II

Herbert G. Stepp, Ludwig-Maximilians-Universität München (Germany)

Dominic J. Robinson, Erasmus Universiteit Medisch Centrum Rotterdam

(Netherlands)

Modeling

Stefan Andersson-Engels, Lunds Tekniska Högskola (Sweden)

Alfred Vogel, Universität zu Lübeck (Germany)

Clinical Laser Therapy

Raimund Hibst, Universität Ulm (Germany) 


\section{Introduction}

One decade ago, the development of novel therapeutic laser and light applications in medicine focused on the investigation of light tissue interactions as function of photon (power) density and dielectric properties of the tissue. Some of this work is still ongoing and focuses more on the long term outcome. Examples thereof in these proceedings include partial porcine kidney resection (73731B) removal of atherosclerotic plaque (73731E), photodynamic therapy of skin disease (73730S) and lentotomy, the treatment of presbyopia, the loss of elasticity of the crystallize lens $(73730 \mathrm{H})$.

Now that lasers achieving $>10^{20} \mathrm{Wcm}^{-2}$ have been aimed at most common tissues and their immediate and long term responses are known, the attention of research is shifting towards exploiting this knowledge of tissue response towards maximizing the therapeutic efficacy. Maximizing efficacy in turn requires improved treatment planning, on-line treatment guidance, and biological response monitoring. A second more recent development is the exploitation of our knowledge of laser tissue interaction in biology which will become more important with recent development in molecular and cell biology as it becomes evident that single cells or small clusters of cells are driving biological and thus medically relevant processes.

Techniques to perform an intentional modification or therapies on individual cells, or small tissue volumes, require localization of the photon absorption in space and/or time such as through the use of: nanoparticles (737308), femtosecond exposure transient micro bubbles (73730D), localized x-ray sources $(73730 \mathrm{~N})$, or micro-structuring of non-biological targets for prosthesis development (73731 A). It is anticipated that this segment of "therapeutic" applications will continue to grow, as significant engineering challenges will need to be overcome which most likely will be unique for a rather large range of potential applications in medicine already apparent in the above list.

In respect to improving clinical delivery and therapeutic efficacy, modeling of therapies is becoming more prominent. Novel computing platforms such as graphic processing units (GPU), which become more easily accessible to the scientific community (see 737313, and 737315) will become more pervasive for these tasks. Modeling aspects covered here range from light penetration in skin (737316), temperature fields due to laser irradiation (73731R), to the use of corneal scattering for keratoplasty optimization (73731Y).

Also more prominent is the development of techniques which will enable monitoring of treatment progress, such as detection of tissue denaturation in real time (73730E), use of optoacoustic transients for retinal photocoagulation (73730K), and photo-bleaching of the eye's lens (73730I). Particularly within this 
line of research, the separation between therapeutic and diagnostic laser application becomes fluid.

The expansion of laser therapies to a whole range of different applicants is also noticeable, ranging from laser osteo-perforation in bone disease (73731T), to endovenous laser treatment (EVLT) (73731S).

Only the treatment monitoring work provides instrumentation development, see (73731M) and (73730P) hinting that laser and light sources for therapeutic applications have matured sufficiently and reached a commodity status.

The future will demonstrate if this trend will continue, away from light source development to real-time therapy monitoring technologies combined with a priority treatment monitoring.

The chairs thank the presenters for their contributions, and the audience and the authors for top information transfer and fruitful discussions. Thank you for making Therapeutic Laser Applications and Laser Tissue Interaction 2009 a scientifically interesting conference within the European Conference of Biomedical Optics 2009.

Lothar D. Lilge Ronald Sroka 